\title{
MITO, SACRALIDADE E TIRANIA NO ÉDIPO TIRANO
}

\author{
Francisco Marshall
}

RESUMO: As the most accomplished version of the Greek myth of Oedipus, the tragedy Oedipus Tyrannus of Sophocles is the basic source for the understanding of many problems in the interpretation of cultures (Greek and others). Nevertheless, it's a document strongly related to its own social and historical context. Aiming to reach cardinal meanings of this masterpiece, hereby we will do a close reading of the Second Stasimon (vv. 863-910), considering its main interpretative problems and perceiving the many ways it connects the religious ethics to the idea of social and political order. Hence we can also explain the meaning of tyranny in this tragedy as well as in its communicative context.

PALAVRAS-CHAVE: Édipo, tirania, sacralidade, mito, segundo estásimo, Atenas.

Mercê de excelentes estudos eruditos que se desenvolveram ao longo do século XX, hoje conhecemos bastante do mito de Édipo fora e além da tragédia de Sófocles. Inventariado em todas as suas expressões e variantes (ROBERT, 1915 e CROISET, 1935) e colocado em contextos comparativos universal (PROPP, 1944 e EDMUNDS, 1985) e helênico (DELCOURT, 1981), este mito encontra-se hoje situado em um ótimo paradigma interpretativo, um paradigma que o preserva atualizado como tema e problema para a reflexão. Isto permite que o humanismo continue encontrando em Édipo referências tais como as que levaram Aristóteles a fundar a crítica literária - em sua Poética, inteiramente baseada no Édipo Tirano de Sófocles - ou como as que levaram Freud (1900) e Lévi-Strauss (1955) a inaugurar vertentes fundamentais da cultura e da reflexão contemporâneas.

Os maiores avanços científicos no estudo deste mito não se realizaram no âmbito das grandes disciplinas fundadas por Freud e Lévi-Strauss, a psicanálise e a antropologia estrutural, mas sim no campo da filologia clássica, da crítica histórica e literária, dos estudos clássicos em seu contexto interdisciplinar de rigor e erudição. Entretanto, devido ao sucesso da psicologia freudiana ao longo do século - um sucesso enraizado no mito antigo e seus nomes -, Édipo se tornou também um ícone cultural, e hoje qualquer cidadão mediano tem uma vaga idéia do que seja Édipo e seu mito, sem necessariamente ter qualquer noção de quem sejam Tirésias, Creonte ou Sófocles na ordem dos fatos. Paradoxalmente, se o mito de Édipo ajudou a gestar a psicanálise, esta terminou por trazer ao mundo contemporâneo uma vez mais o mito, pois hoje a noção mais comumente relacionada a Édipo é a lembrança do parricídio e do incesto, terreno próprio do mito, e não da psicanálise e de suas injunções especulativas sobre a sexualidade, o recalque original ou a formação cultural das neuroses.

Caso considerássemos todas as conseqüências acadêmicas, sociais e culturais decorrentes das obras de Freud e de Lévi-Strauss, e se contemplássemos todas as diversas ramificações e manifestações que este mito fecundo fez surgir nos últimos cem anos, do cinema ao fanzine, da ficção à Universidade, do teatro às guildas psicanalíticas, do pasquim à novela, veríamos o quão enraizados esta tragédia e seus mitos estão em nossa cultura. Pois este século vinte está marcado por abrigar uma das maiores retomadas e revitalizações do mito de Édipo, um mito perfeitamente atualizado e bem alojado na mente do homem contemporâneo.

Aqui, entretanto, não se pretende nem retomar o fio da erudição, nem acatar de imediato suas projeções e especulações, menos ainda realizar a ensaística do século de um ponto de vista edípico, mas sim examinar um pouco do próprio texto do Édipo Tirano de Sófocles, e perceber como em formulações decisivas deste drama se expressam noções e categorizações que iluminam muito nosso entendimento sobre o todo da tragédia e sobre seu contexto de enunciação. Estas noções e categorias respondem a

Francisco Marshall é professor do Departamento de História do IFCH da UFRGS 
muitas questões quanto ao pensamento social e religioso vigente nos enunciados deste texto de Sófocles, dizem da sacralidade e seus conflitos no mundo da polis democrática e nos transmitem graves imagens do poder e da natureza humana, imagens plenas da grandiloqüência solene própria do discurso trágico.

Convém preliminarmente lembrar que o título da obra, tal como a conhecemos hoje, era muito provavelmente desconhecido do próprio Sófocles, atribuído que foi por gramáticos alexandrinos - pois o próprio Aristóteles refere-se a ele apenas como "o Édipo de Sófocles" ou "o Édipo". "De Sófocles", possivelmente por situar-se entre outros "Édipos" conhecidos ao tempo de Aristóteles, mas não por nós, que só sabemos de alguns fragmentos, inclusive dos restos de um escrito por Ésquilo em uma trilogia sobre a maldição da casa de Laio, reconstruída hipoteticamente por Lloyd-Jones (1971). Ao apor "tyrannos" ao nome Édipo do título, entretanto, os alexandrinos conformaram uma curva interpretativa a encaminhar a leitura desta tragédia, uma curva muito significativa e que terá modernamente, especialmente em J.-P. Vernant e em M. Foucault, as conseqüências analíticas mais rigorosas. O tirano e a tirania, anexados ao próprio nome da obra tanto quanto efetivamente relevantes na estrutura da tragédia, interessam a nós, modernos, pois através deles podemos decifrar as relações entre este mito terrível, sua formulação dramática por Sófocles e a realidade histórica de um poder anômalo - o poder da tirania, tal como vista e estigmatizada pela comunidade ateniense do século $\mathrm{V}$ a.C..

Efetivamente, o poder e a tirania são temas centrais deste drama, como o são também a verdade, a inteligência, os processos investigativos e a condição humana, entre outros - um drama multicentrado, extremadamente polissêmico e por isso mesmo aberto a olhares e recortes tão heterogêneos que parecem mesmo se excluir ou referir-se a textos diferentes. A tirania, além de central, goza de um estatuto referencial sui generis na tragédia, pois tanto ela produziu uma sentença de epígrafe já clássica em obras que tratam da tirania - hýbris phyteúei týrannon - "insolência gera tirano", v. 873, como apareceu em vários momentos com múltiplas e complexas cargas de significado. Por trás disso, temos o poder exercido por Édipo como um dos eixos estruturadores da narrativa, um poder que se desenvolve em completa simetria com a evolução trágica do protagonista em cena, do estado de prestígio e autoridade do prólogo ao estado de total derruída e desterro do êxodo.

Para investigarmos um pouco mais de perto como se conformam no texto da tragédia Édipo Tirano de Sófocles as reflexões e referenciações à tirania, destacaremos aqui um locus central da tragédia, o segundo estásimo, uma intervenção do Coro situada entre o segundo o terceiro episódios (vv. 863-910), o qual desponta no drama como um dos momentos de maior gravidade, em que em tom solene são proferidas reflexões sobre a ordem do mundo, o respeito à religião, a força das profecias e o comportamento desmedido - temas que conectam diretamente a ética religiosa à atitude social e política, e à própria viabilidade do mundo civilizado. Este estásimo tem recebido considerável aporte de crítica especulativa, e pode nos permitir, através de uma leitura atenta, percorrer quase todos os problemas fundamentais desta tragédia.

Pelo que se conhece das atitudes religiosas de Sófocles, seja por informação biográfica, seja pela apreciação de sua obra supérstite, é possível especular-se que o autor esteja no segundo estásimo expressando suas próprias convicções - ou ao menos não objetaria os pontos que o Coro anuncia com tanta grandiloqüência, piedade e beleza. A atitude deste grupo piedoso e reverente, ao estabelecer uma relação entre a harmonia mundi e a ética religiosa, entre a ordem social e a piedade e respeito pelos bens sagrados, entre o excesso de poder e os males éticos da impiedade, não propenderia a desagradar a um sacerdote de culto heróico, a um expoente do mundo mais tradicional da cultura grega (especialmente em matéria religiosa), como Sófocles. Este foi um autor sempre sensível às atualidades políticas e intelectuais de sua época, disso suas tragédias dão claro testemunho, mas ainda assim sustentava sua criação sobre fundamentos e conceitos marcadamente religiosos. Apesar da possibilidade aberta neste estásimo - de se poder inferir o autor pela obra, ou de se identificar um ao outro -, as proferições aí são realizadas por um personagem bastante bem caracterizado - o Coro -, e não só correspondem à reação compatível com sua identidade ética, como se inserem e se justificam em uma dinâmica de ações e em uma certa seqüência de informações a ele apresentadas. Ou seja, antes ou além da biografia do autor, enseja-se este estásimo pela unidade de caráter e de ação ${ }^{1}$ do Coro - que é, afinal, quem de fato canta e dança esta ode.

Antes de passarmos à leitura, devemos considerar que esse canto coral se caracteriza por manifestar com veemência a angústia vivida pelo Coro de cidadãos tebanos face a uma situação de perplexidade gestada inteiramente na e pela dinâmica dramática. Sem dúvida que esta situação envolve bem proximamente vários personagens cujas atitudes podem estar na mira do Coro - Édipo em particular, talvez Jocasta ou Laio, tangencialmente; não se excluem Tirésias, ou profetas em geral, e, como guardiães

\footnotetext{
1. Não somente no sentido aristotélico (cf. Poética, 1451a15 ss.) de uma unidade de toda a ação imitada, mas também da unidade e necessidade das ações do Coro como personagem do drama. Cf. também Torrano (1996).
} 
do mundo e da religião, Zeus e Apolo. A crítica erudita tem se exercitado preferencialmente na identificação do alvo das críticas, com proposições tão diversificadas que chegam a soar satíricas, ao revelar o grau de relatividade de nossas especulações. Entretanto, antes de se considerar quem pode ser o destinatário das críticas e denúncias ora apresentadas (se de fato o é alguém em particular), pode-se tentar definir qual a verdadeira denúncia aí versejada, o que pode ser feito percebendo-se o momento e o contexto de enunciação tal como visto e sentido pelos cidadãos que integram o Coro, em estreita correlação com o encadeamento de ações que precede e subjaz a este estásimo.

No momento em que o Coro enuncia este canto, justifica-se perfeitamente o crescimento exponencial de seu temor. No espírito grandiloqüente e solene característico do texto trágico, a situação dramática é aqui sentida e pensada pelo Coro em suas últimas consequiências éticas, políticas e existenciais. Mas, fazendo-se a recomposição de sua trajetória como personagem do drama (seu ponto de vista ou unidade de caráter), vê-se como este segundo estásimo relaciona-se diretamente aos pressupostos lógicos a ele apresentados, no encadeamento de ações e discursos da tragédia, o que deve ser considerado na interpretação dos conceitos apresentados, cuja gravidade e generalidade não significa um distanciamento com relação à situação particular do drama, tal como vivida por esta figura dramática. Sinteticamente, essas são as principais informações que se apresentam até este momento ao Coro (como aos espectadores):

1. A peste que dizima Tebas é causada pela permanência de um agente impuro sobre o território da cidade: o assassino impune do rei Laio, como indicou Apolo através de consulta oracular;

2. Édipo, o rei no exercício da autoridade régia, deve investigar e revelar o criminoso, eliminando-o da cidade;

3. Afastada a via numinosa da investigação da verdade (por meio das revelações de Tirésias), e preterida a hipótese de conspiração (que ao Coro afigurou-se desde cedo como temerária), as investigações de Édipo levantam a primeira grande suspeita baseada em informações testemunhais (ainda que a princípio indiretas e carentes de averiguação), a partir da comparação das ações pregressas de Laio e de Édipo: Laio foi morto em uma encruzilhada, em uma encruzilhada Édipo matou alto dignatário: logo, Édipo teria matado Laio.

Este é o teor das informações que são apresentadas no transcurso da ação trágica desde o início do drama, cabendo enfatizar as informações produzidas no episódio anterior, através da lembrança e da exposição pública, por Jocasta e por Édipo, de histórias com instigantes pontos em comum. De acordo com as lembranças de Édipo, narradas em público (vv. 771-833), tudo confirma a possibilidade de que ele seja de fato o regicida, exceto o detalhe assimétrico de um número. O protagonista teme que seja ele o assassino do rei, uma hipótese plausível que ao final do segundo episódio permanece em dúvida, sem a confirmação definitiva.

Esta grande possibilidade que Édipo levanta, de que ele tenha já sido identificado como o próprio regicida, ainda é desgraça muito pequena face a sua completa tragédia, logo a seguir descoberta, mas aos olhos do Coro ela já teria consequiências terríveis, e compatíveis com a grave angústia com que ele canta e dança no segundo estásimo. Duas grandes inquietações podem, a partir de então, abalar o Coro. Além de estar seu rei afetado ou ameaçado pelos indícios que se vão produzindo, deve ocorrer ao Coro outra possibilidade igualmente grave, relativa à eficiência do saber profético de Apolo.

As profecias concernentes a Laio, conhecidas do Coro (apresentadas por Jocasta, v. 711-4, e reafirmadas às vésperas do segundo estásimo, vv. 852-7), diziam que este rei morreria pelas mãos do próprio filho, mas, para surpresa de quem acredita no poder dos Deuses imortais, eis que o assassino parece ser filho não de Laio, mas de Pólibo e Mérope. Que teria sido feito, neste caso, das previsões de Apolo? Tal como Jocasta, o Coro vê surgirem condições para se descrer dos oráculos, posto que falíveis. Embora preocupante, a atitude da rainha quanto à mântica pode ser menos grave ao Coro do que o arranjo de fatos que a enseja, e do que a ameaça maior de que se oculte a Zeus o que se passa em seus domínios, temor manifestado no encerramento deste canto coral, nestes versos:

"Eia, ó soberano, se és corretamente afamado,

ó Zeus, senhor de todas as coisas, não escapem

a ti e ao teu imortal império.

Perecem os antigos oráculos de Laio ${ }^{2}$

Já os oráculos são abandonados

e em nenhum lugar Apolo é honrado:

vai-se a religião."

(vv. 903/10)

\footnotetext{
2. Com a conjetura de Jebb (phthínonta gâr Laîou <palaíphata>), sobre lacuna ainda carente de melhor exame paleográfico (cf. KAMERBEEK, a.l.).
} 
Apolo, senhor das profecias, já não recebe culto, esvaem-se as honras dos Deuses, a quebra de sacralidade leva à possível morte da religião. Este lamento pelo desconcerto do mundo assinado pelo Coro, dando fecho ao segundo estásimo, deve iluminar o entendimento de toda a crítica contundente à ética religiosa e à ordem do mundo, tal como desenvolvida nos trechos iniciais deste estásimo. A religião é ameaçada não exatamente pelo desdém de Jocasta, mas sim pelo não cumprimento da predição feita a Laio (v. 906), ou seja, pela falência da potência mântica de Apolo, que afastaria o Coro dos principais altares proféticos da Grécia clássica:

"Não mais irei ao intocável umbigo da terra veneranda,

nem ao templo de Abas

nem a Olímpia

se estas [profecias ${ }^{3}$ ] não se ajustam

manifestas a todos os mortais."

(vv. 897/901)

Delfos, "umbigo da terra", (v. 897) e Abas, (v. 899) no noroeste da Fócida, (HERÓDOTO, VIII, 33),ambos altares proféticos de Apolo, e Olímpia (v. 899), sítio do grande altar de Zeus no coração do Peloponeso, onde também se anunciavam oráculos de Zeus ${ }^{4}$. A atenção do Coro se dirige aos altares proféticos, como se a religião dependesse fundamentalmente da eficiência das profecias, por cuja consecução roga-se diretamente a Zeus - mesmo que para a realização das profecias o rebento de Laio e Jocasta, contrariando o que se supunha até então, devesse ter sobrevivido para um dia matar o próprio pai. A prova de eficiência dos Deuses (Zeus e Apolo) esperada pelo Coro é a exata realização das previsões de Apolo: "se estas profecias não se ajustam / manifestas a todos os mortais" (vv. 901/2), i.e., se as profecias não se encaixam nos fatos (não se realizam), aparecendo claramente como paradigma para todos os mortais ${ }^{5}$.

A realização da profecia (Laio morrer assassinado pelo próprio filho), por outro lado, desautorizaria expressões de ceticismo quanto à mântica, como as de Édipo e especialmente Jocasta, reafirmando o império e a força dos imortais. Não deixa de ser provocante o fato de que a fé do Coro em um mundo moral, ético e político superior, um mundo ordenado pela religião, deva ser posta na dependência da autoridade e verdade justamente da profecia, que tanta polêmica desperta no drama como na vida histórica, e cujos limites e problemas já haviam sido percebidos até mesmo pelo próprio Coro, no primeiro estásimo (vv. 463-511), quando a profecia é desprezada por não ter valor de prova, e onde os saberes são relativos e intercambiáveis (vv. 489-506).

Como reza e prece à potência divina de Zeus, este estásimo deixa aberta a alternativa de superação da ameaça, pois mesmo a lastimada falência dos oráculos (que teria por conseqüência a perda da fé nos Deuses) é colocada pelo Coro em forma condicional:

"Se alguém desdenhosamente com feitos ou com palavras caminha, sem temer a justiça nem venerando imagens dos templos dos Deuses, escolha-se para ele péssimo destino, mercê do orgulho funesto;

Se não ganha o ganho justamente nem se afasta das impiedades, ou insane toca as coisas intocáveis ${ }^{6}$

Há então neste caso alguém que possa repelir da alma as setas da raiva ${ }^{7}$ ?

Se tais atitudes são honradas, por que devo dançar?" (vv. 883-96)

Se tal é a ordem dos fatos, que a impiedade pode prosperar e a justiça ausentar-se (vv. 883-91), se atitudes ímpias são honradas (v. 895), se os oráculos não se impõem como referência aos mortais (vv. 900-1), então o Coro pode vir a lastimar a morte definitiva da religião, com todas as péssimas

\footnotetext{
${ }^{3}$. Cf. Jebb e Kamerbeek (a.l.), o qual assim explica este pronome táde: "desde que nas linhas precedentes três santuários oraculares foram mencionados, táde deve em primeiro lugar referir-se a um oráculo. 906 ss. tornam claro que este deve der o oráculo de Apolo a Laio sobre sua morte.".

${ }^{4}$. A cargo dos Iamidas, cf. Píndaro, VI Olímpica, v. 70.

${ }^{5}$. Ou, como bem traduz Jebb (a.l.): "(...) if these oracles fit no issue, so that all men shall point at them with the finger.".

6. Com Jebb: thíksetai, em vez de héksetai (Dain).

7. Kamerbeek e Dawe concordam em que é impossível entender a sentença com o thymôi transmitido, em correlação com érksetai, para os quais várias hipóteses têm sido especuladas (e.g., Jebb: theôn / eúksetai; Schadewaldt apud Kamerbeek: thymôn / arkései; e Dain: thymoû / eúksetai); as opções não eliminam o risco de se interpretar tal passagem, malgrado a existência de alternativas bastante provocantes.
} 
conseqüências éticas que julga disto decorrentes. Estando negada a profecia como via de comunicação entre Deuses e homens, entende o Coro que o próprio interesse dos Deuses no mundo humano estaria sob suspeição, cabendo-lhe inclusive temer pela efetiva aplicação da justiça no caso da morte de Laio ${ }^{8}$. Da mesma forma, vigorando um mundo em que se esvazia a importância dos Deuses, permite-se o Coro conjeturar acerca do sentido de se permanecer realizando a atividade cultual (tí dê̂ me khoreúein?, v. 896), seja aos Olímpicos, seja sob a forma de arte trágica - se aceitarmos um duplo sentido nesta sentença supracitada, referindo-se a cultos em geral como também aos coros trágicos. Este estado desastroso temido pelo Coro é apenas hipotético, pois no estásimo se evoca o alto nome de Zeus, cuja potência se espera ver atuando no combate ao sacrilégio. $\mathrm{O}$ episódio seguinte tratará de oferecer ao Coro a resposta completa a suas ansiedades e preces, pois todas as profecias vão revelar-se como verídicas, identificando-se, ainda que precariamente (AHL, 1991) ao criminoso e, assim, assegurando-se a supremacia divina e seu poder regulador sobre os homens e o mundo.

Não foi esta a única oportunidade em que Sófocles condicionou a realização de certos feitos (que de fato se realizam imediatamente no drama) à veracidade e força do saber profético ${ }^{9}$, arranjando dramaticamente provas da eficácia das profecias. Como John Peradotto (1991) apontou, interpretando outros aspectos do drama, pode estar-se manifestando aí uma postura ideológica conservantista do autor, zeloso de lutar em defesa da sacralidade e da ordem na religião, e que talvez esteja reagindo aos vários ataques que estas sofreram desde o início da guerra entre peloponésios e atenienses ${ }^{10}$. A súplica do Coro, deve-se notar, parece ser ouvida por Zeus, pois eis que imediatamente os oráculos se revelam plenamente atuantes.

Mas um outro fator pode estar contribuindo para angustiar o Coro neste segundo estásimo, e deixá-lo temeroso quanto à ordem social. O problema pode ser colocado em um enquadramento político, sob o enfoque de um ponto de vista da história política, o que será sempre uma perspectiva fundamental em um drama que trata de um regicídio e das atitudes de um rei na cidade em crise. Se Édipo de fato matou Laio, como parece ao final do segundo episódio, configurar-se-ia, então, um episódio traumático da história da realeza tebana, pois até então se supunha que ele exercesse o poder com base em sua sabedoria decisiva, por sua gnóme (v. 398), mas os novos indícios insinuam que ele teria aberto caminho ao trono por meio da violência, bía, ao eliminar o antigo rei. O assassinato de Laio é o fato preliminar neste momento da sucessão real em Tebas (de Laio a Édipo), e nele Édipo já se apresenta como conquistador.

É bom lembrar que Apolo não denuncia diretamente o parricídio e o incesto, mas sim o regicídio impune, e esta grande questão já começa a se esclarecer a partir do verso 707. É muito possível que esteja contida nos desígnios do Deus a revelação da verdadeira identidade do filho de Laio, mas, até o início do segundo estásimo, não há a menor evidência quanto a isto. Ao contrário, Édipo é diretamente referido com filho de Pólibo, e distinguido da casa dos labdácidas (vv. 489/96). Que Édipo tenha recebido poder e trono em Tebas após ter vencido a Esfinge com seu intelecto, é perfeitamente compreensível e lógico. O trono estava vago, e chega então um herói e supera a todos pela força de sua inteligência, demonstrando benevolência para com a cidade (vv. 46-51). O fato desconhecido até então pelo Coro era que este mesmo salvador fora na verdade o assassino do rei, antes mesmo de enfrentar a Esfinge. Assim, além da mudança quanto à natureza do fundamento do poder régio de Édipo (violência, em lugar de saber), coloca-se aí também a precedência de sua responsabilidade criminosa sobre a própria conquista da realeza, pois aquele viandante que tentou (com êxito) decifrar o enigma, era já então o assassino do rei, e como tal ascendeu ao trono, desposou a Rainha, e reinou muitos anos. Que magnífica conspurcação da sacralidade real, onde o único mistério é compreender como foi por tanto tempo tolerada por Apolo e Zeus ${ }^{11}$. No tempo da cidade, onde por muito tempo e por diversas razões não se investigou o regicídio, permaneceu desse modo subjacente a grande lacuna (e imprecisão) de legitimidade no poder de Édipo, agravada pela quebra de sacralidade (o assassino reina). Isto implica que o poder de Édipo esteja também desde o princípio do drama assentado sobre precária base, e que a peste lhe corroa o reino, que o povo lhe reclame e que Apolo o denuncie. Neste caso, o tirano indicado ao verso 873 (hýbris phyteúei týrannon), se for de alguma forma referenciado por uma forma comum do conceito de "tirano" em Atenas na primeira metade do século V

\footnotetext{
${ }^{8}$. Cf. Carey, C., 1986, pp. 175-9; anota Carey: "o Coro não faz distinção entre punição divina e revelações divinas através de oráculos" (p. 178).

${ }^{9}$. Cf., e.g., Electra, vv. 474 ss.

10. Tucídides, II, 53; cf. Pignarre, R., 1964, p. 10.

11 . No tempo dos homens, e da cidade, a explicação, oferecida por Creonte foi de que tiveram então que encarar a Esfinge de variegados cantos (vv. 130-1); também Édipo, contrariando a lógica de auto-proteção que ele mesmo formula para justificar seu interesse no caso (vv. 139-41), não se motivara até o início do drama a apurar a morte do antecessor.
} 
a.C. (um autocrata que, estando fora da linha de sucessão, tenha conquistado o trono pela violência), poderia ser identificado pelo Coro como sendo exatamente Édipo, sem nenhuma contradição aparente.

A hýbris que, como diz o Coro, engendra ou nutre o tirano, neste caso poderia ser vista seja como o orgulho de Édipo por um saber que afinal não é tão fundamental como se supunha (pois chegou ao trono não só por este saber, mas antes pela violência), seja como o descontrole emocional de quem comete um assassinato, como disse Édipo, tomado de cólera (v. 807). Nenhuma manifestação do Coro, entretanto, sustenta a hipótese de que ele pretenda incriminar ou condenar Édipo: quando este relata que matou alguém de alta dignidade, possivelmente o rei, tem reafirmada por seus súditos uma solidariedade que não lhe faltará até o final do drama, assim como inexistem neste passo referências à falsidade ou à precariedade do saber e do poder de Édipo. Não há que se buscar em nada além da piedade e do respeito às tradições religiosas o sentido das críticas do Coro neste estásimo. É na ética religiosa que pensa o Coro desde o início da ode:

"Que o destino me encontre sustentando

a piedosa pureza em todas

as palavras e feitos, tal como dispõem

as leis que marcham acima, geradas

no celeste éter ${ }^{12}$, o Olimpo só

lhes é pai, nem mortal

natureza de homens as

concebeu nem jamais

as adormecerá o oblívio:

o Deus é grande nelas, nem envelhece."

(vv. 863-72)

O Coro zela pela manutenção de um alto estado de piedade e pureza (v. 864), e rechaça a postura ímpia de quem vive sem justiça e sem venerar as imagens dos Deuses nos templos (vv. 886-7). Após a indicação de seu ideal de piedade e da alta relevância atribuída à preservação da religião e de suas leis, o Coro autoriza-se a partir para a formulação de suas críticas mais contundentes aos desvios em matéria de ética religiosa e social. É neste contexto que se profere a poderosa sentença já destacada de condenação ao tirano (hýbris phyteúei týrannon):

"A insolência gera o tirano.

Quando a insolência muito se sobre-repleta futilmente

sem oportunidade nem vantagem

subindo aos píncaros pontiagudos

necessariamente despenca ao infortúnio ${ }^{13}$

onde não serve nenhum

serviço dos pés. Suplico ao Deus

nunca abandonar os bons combates pela cidade:

não deixarei jamais de ter o Deus protetor."

(vv. 873-81)

A hýbris, que podemos traduzir aproximativamente por insolência, desmedida, ultraje, excesso ou violência arbitrária, entre outras alternativas, deve ser entendida aqui em seu sentido religioso, pois é nítida a sua contraposição à "piedosa pureza em todas as palavras e atos" ${ }^{14}$, professada pelo Coro como ideal ético na estrofe antecedente. A hýbris assume aqui o sentido mais preciso de transgressão às leis religiosas, ou a leis morais e sociais fundadas na precedência e superioridade do divino sobre o humano. É o sentido exarado por Ésquilo em um canto coral da tragédia Eumênides, em que se lê que " $a$ desmedida [hýbris] é filha da impiedade" ${ }^{15}$ (v. 534); a impiedade (asébeia), por seu turno, era sentida como um crime contra o Estado em Atenas (EHRENBERG, 1960, p.79.), e passível de sanções penais bastante rigorosas - como pôde oportunamente descobrir Sócrates. O desrespeito às leis divinas, como observa com precisão Kamerbeek:

“(...) conduz à tirania, (týrannos é aqui usado in pessimam partem), ou seja: um rei que puder negar a ordem divina das coisas se tornará um tirano e a ausência de leis se tornará comum em sua cidade e levará à ruína dos cidadãos tanto quanto dele próprio.”

(KAMERBEEK, 1967, pp. 175-6)

${ }^{12}$. Quanto ao diá + acusativo, cf. Kamerbeek, p. 174, ad vv. 866-7: "é um costume épico que ocorre eventualmente na poesia lírica e na tragédia.".

13. Aqui há texto obscuro, com emendas apenas aceitáveis. Ficamos com Jebb: apotmotátan órousen eís anágkan.

14 . "eúsepton hagneían lógon / érgon te pánton" (vv. 864-5); cf. Kamerbeek, ad v. 873.

15. "dyssebías mèn hýbris tékos" (Ésquilo, Eumênides, 534). 
O emprego dado à palavra týrannos ao v. 873, portanto, é tributário da concepção mais negativa possível de tirania ${ }^{16}$, pois o tirano é aí identificado à suprema excrescência política, à mais grave anomalia que pode ameaçar a vida civilizada. Não há elementos convincentes para que se possa identificar a Édipo como este indesejável autocrata, pois, salvo a hipótese ex absurdum de o Coro agir com hipocrisia, ele é tido como um líder amado e respeitado até o final do drama. Enquanto prosseguir batalhando pelo atendimento à ordem de Apolo, e enquanto manifestar qualquer temor pelos oráculos, o protagonista continuará a merecer a confiança do Coro. Abandonando a hipótese de que alguém em particular, dentre as pessoas do drama ou da vida histórica, seja taxado de týrannos, e matizando o termo pelo contexto e pelo âmbito semântico destas estrofes e antístrofes, este destaca-se como expressão de um superlativo estado de anomia, resultante da impiedade, estado em que os sãos costumes se corroem. Quanto a isto pode-se ler também Tucídides lastimando na mesma índole, ao descrever o estado de anomia que a peste impôs à cidade de Atenas no dealbar da Guerra do Peloponeso, ocasião em que:

"O temor pelos Deuses ou pelas leis dos homens não detinha ninguém, muitos consideravam que dava no mesmo ter piedade ou não, pois viam todos perecendo igualmente (...)."

(Tucídides, II, 53, 4)

A calamidade descrita por Tucídides, que aconteceu algum (pouco) tempo antes da apresentação desta tragédia, chegou a pontos muito críticos: desrespeito aos tradicionais costumes funerários, perda do pudor e desamor à honra, tornando-se corrente a entrega aos prazeres do momento (Tucídides, II, 53, 3). O quadro desolador da doença, seus sintomas terríveis, mortes em profusão, escassez de recursos, é culminado pela desagregação dos costumes, estado aí designado como de anomia, em que já não vigoravam quaisquer leis.

Tucídides deplora o desrespeito às leis divinas e humanas, mas para Sófocles, ou melhor, para o Coro no segundo estásimo, a só ausência de um mundo regrado pelo temor ao poder olímpico inviabiliza desde o princípio a existência de qualquer outro mundo normatizado e são. As leis que fundamentam a piedade do Coro são "leis que marcham por cima" (nómoi (...) hypsípodes: "que têm seus pés nas alturas", v. 866), “celestes" (ouranían, v. 866), e "geradas no éter" (v. 867), filhas somente do Olimpo (v. 867-8). O descaso para com as normas celestes e a conseqüente impiedade levam o homem a um estado de embriaguez em que ele poderá saciar-se e inflar-se em orgulho, chegar aos píncaros, e depois tombar completamente, nada mais lhe valendo então, nem os seus próprios pés (vv. 873-8).

Naturalmente que a crítica à impiedade poderia ser um comentário do Coro à atitude de absoluto descompromisso para com os oráculos manifestada no episódio anterior por Jocasta, e até certo ponto acompanhada por Édipo, e seria aceitável que um espectador antigo, tanto quanto um leitor moderno, pudesse fazer esta identificação. A atitude de Jocasta bem se encaixa em um perfil incompatível com a piedade do Coro, e propenso a fundar o estado de anomia que este teme, pois a rainha, ao desprezar a arte profética, nem sequer contrapõe um outro critério de saber, de ordem ou de fundamentação à vida (tal como poderiam se apresentar a gnóme, o lógos ou o nómos seculares, de políticos e filósofos), mas simplesmente propõe um abandono dos recursos proféticos. Jocasta é acima de tudo a denunciadora da (aparente) falência dos oráculos, é ela quem reapresenta e despreza os oráculos de Laio à véspera do segundo estásimo: Lóxias previu que Laio morreria pela mão de seu filho (de Jocasta), mas o que (aparentemente) se viu foi algo bem diverso (vv. 851-6).

Esta atitude da rainha é reiterada após o segundo estásimo - efetivamente, ela estava ausente quando o Coro decantou seus graves temores. Neste passo (terceiro episódio), entretanto, é salvaguardado o respeito a algum poder divino, embora desvinculado da verdade da profecia. A rainha exulta em poder reafirmar expressões de autonomia a partir da chegada de nova prova (aparente) da falência dos oráculos (a morte de Pólibo, não por Édipo, mas pela idade), momento em que são retomadas com satisfação as críticas à profecia, cujo proveito lhe parece ser inexistente:

"Por que o homem temeria, para quem os decretos da fortuna

são soberanos, e tem clara presciência de nada?"

(vv. 977-8)

A fortuna (týkhe, v. 977), como bem assinala Jebb, "não envolve aqui a negação da ordem divina no governo do mundo, mas apenas o poder do homem de compreender ou prever seu curso" (Jebb, 1966, p. 131). Para o Coro, entretanto, o valor das profecias e o poder divino estão condicionados reciprocamente. Como última observação acerca das possibilidades de se identificar Jocasta como o alvo do temor e da reprimenda do Coro, cabe notar a ausência, na economia dramática e fora deste segundo estásimo, de quaisquer manifestações textuais de crítica às atitudes políticas da rainha, qualquer reação de temor ou apreensão que corresponda à grande inquietação contida nos versos 873 ss.. Na verdade, desde

\footnotetext{
16. Jebb também o considera, dizendo que não se trata de "um 'príncipe' - nem mesmo, no sentido grego usual, um governante absoluto e inconstitucional (bom ou ruim) - mas, em nosso sentido, 'um tirano,".
} 
A. W. Schlegel (ou mesmo da época dos escoliastas ${ }^{17}$ ) a crítica tem apreciado muito apontar a suposta "frivolidade" de Jocasta ${ }^{18}$, sem considerar nem remotamente a racionalidade de seu ponto de vista, e daí passando a pôr sua cabeça na guilhotina ética e moral montada pelo Coro no verso hýbris phyteúei týrannon. Como admoestação de ordem geral, poderia estar visando ainda muitas outras pessoas, do mito, do drama, ou da vida histórica ateniense, como catalogou I. Errandonea ${ }^{19}$, ao propor Laio como verdadeiro titular das críticas, temores e denúncias do Coro. Em que pese a validade especulativa das várias hipóteses propostas para a identificação do elemento supostamente denunciado no segundo estásimo, e mesmo o proficiente evidenciamento de muitas destas, talvez este seja um falso problema a condicionar a resposta, sendo mais proveitoso considerar o segundo estásimo em sua generalidade, vendo-o antes como lamento por uma situação preocupante, crítica de um tipo de atitude decorrente desta situação, e especulação quanto a suas consequiências sociais. É, por fim e acima de tudo, uma prece ao magnífico Zeus, pánt'anásson, (v. 904), antes do que a descrição de personagens particulares do drama ou do século.

\section{TIRANIA}

Esta imagem da tirania, associada à falência da ordem moral, social e política, vem somar-se a outras imagens e conceituações do regime tirânico referidas pelo drama, tendentes a denunciar as anomalias desta forma de poder. Não parece proveitoso, entretanto, considerar que seja esta reflexão política condenatória o objetivo da tragédia ou sua doutrinação política, não só porque parte destas imagens e referências à tirania têm incidência secundária, ou porque sejam meras imagens e conceitos utilizados na escrita do discurso trágico, mas especialmente porque avultam outros temas relevantes neste grande complexo polissêmico que é o discurso trágico, não havendo condições para se definir rigorosamente o poder de Édipo como um poder tirânico, ou a tirania como o tema político cardinal da tragédia. Lembre-se a propósito, que a realeza tradicional é também tematizada em vários momentos do drama, e pode, com ressalvas conjunturais, ser eventualmente confundida com a própria tirania. A referência à tirania, neste caso, poderia ser vista como tributária da forma negativa com que o pensamento democrático reflete sobre qualquer forma de poder autocrático - legítimo ou não. O excesso de poder, a concentração de potência decisória em um indivíduo contraria os pressupostos éticos e morais que sustentam o regime de igualdades jurídicas e políticas postulado no âmbito da polis democrática. Há uma longa tradição helênica de reação crítica à desmedida, em que o excesso (de orgulho, felicidade, riqueza ou poder) aparece como momento de uma sina trágica fadada à ruína, e a polis muito a propósito se fez herdeira desta reflexão ética, como expressaram com particular zelo as obras de Ésquilo e de Heródoto. A crítica à forma autocrática de poder pode ser considerada como um tema subjacente à grande maioria dos discursos formulados na Atenas do século $\mathrm{V}$ a.C., e aparece em textos e momentos como um tópico recorrente, sem que seja necessariamente o tema principal das reflexões, e sem que seja, também, uma referência direta a ameaças ou temores conjunturais.

Isto de modo algum quer significar que o poder tirânico não seja problematizado no transcurso do drama, e que não se possam formular sérias questões à ética política, ao exercício do poder e, dentro desta temática, à tirania. Entretanto, mesmo consignando-se certo reconhecimento ao espaço ocupado pela crítica à tirania no Édipo Tirano, convém ter cautela com a hipertrofia desta percepção registrada por vários intérpretes, particularmente quando identificam a derruída trágica do protagonista como decorrente de seus atos enquanto detentor do poder político - sua intolerância para com os interlocutores e mais especificamente a pretensão de domínio tirânico revelada em sua relação com Creonte. Esta proposição poderia nos levar a considerar a tragédia como uma doutrinação contra a tirania, um aviso ou denúncia de Sófocles aos atenienses quanto aos riscos de se produzir um novo tirano em Atenas (ROCHA, 1989, p. 34-5). Deve-se lembrar, entretanto, que não só este propósito doutrinário exclui-se da natureza conflitiva e ambígua da tragédia, como também que a preocupação quanto à tirania pode ser vista como tendo algo de anacrônico no (aliás impreciso) momento político em que se representou esta obra. Esta preocupação foi bastante forte entre os atenienses no início do século $\mathrm{V}$ a.C., época em que a nascente democracia

\footnotetext{
17. Como aventa (sem apresentar evidência ou indicação) Carey, 1986, p. 178.

18. Cf. Errandonea, 1952, pp. 17-8, que elenca uma plêiade de nomes em diversas épocas (U. von Wilamovitz, A. Mueller, Blumenthal, Robert, Lesky, Croiset, Perrota).

${ }^{19}$. Além do partido "por Jocasta" supracitado, há ainda: a) por Édipo (Campbell, Webster, Wolf); b) por Édipo + Jocasta + Creonte (Sheppard); c) por Cléon (Blumenthal); d) por Péricles, para condenar (Hermann) ou para elogiar (Schoell); e) por Protágoras e Péricles (Bruhn); cf. Errandonea, op. cit., 17-32.
} 
ainda temia um retorno ao regime que predominou no século anterior, mas na época em que veio à luz esta tragédia não perdurava mais que um ranço recorrente, malgrado o agravamento da conjuntura política advindo com o desencadear da Guerra do Peloponeso. Poucos anos após a apresentação do Édipo Tirano pôde-se assistir, inclusive, à extinção do principal recurso legal criado visando a prevenção contra a tirania: o ostracismo, aplicado pela última vez em 417 ou 416 a.C. ( FINLEY, 1985, p. 71-2.) Mas não é por este provável anacronismo do temor quanto à tirania (KNOX, 1971, p. 58-9). Que se deve descrer da proposição de que Édipo cai por força de seus atos políticos, mas sim devido à precedência, como desencadeadores da tragédia, de atos anteriores a sua ascensão ao poder (o regicídio e, em certa medida, as transgressões de Laio que deram origem à maldição) e não diretamente relacionados com suas atitudes políticas, tanto quanto de imperativos da ordem do nume relativos a sua existência, imperativos estes que configuram a dimensão propriamente trágica de seu ser.

Para concluir, cabe considerar que a relação entre a sacralidade e a tirania, composta no segundo estásimo sob a forma de uma reflexão ética e moral aplicada à vida social, aparece como uma realização própria do drama, a princípio distante do núcleo mítico fundador, a saga de Édipo. Constitui-se, portanto, em um teor de reflexões próprio da tragédia, enquanto ordenação de ações e sentenças, inscrita na rede de intenções e possibilidades do autor e de seu contexto comunicativo. Neste contexto, é notável que a tirania seja associada ao estado de máxima calamidade possível, quando as leis não-escritas cessam de vigorar, morre a piedade e vão-se os bons costumes. Resta considerar a questão metodológica aí ensejada: a que demandas de sentido podem corresponder tais manifestações, além das contidas no próprio desenvolvimento do drama?

\section{BIBLIOGRAFIA:}

AHL, Frederick. Sophocles' Oedipus; evidence and self-coviction. Ithaca, Cornell U.P, 1991.

ANDREWES, A. The greek tyrants. London, Hutchinson's Un. Lib., 1956.

ARISTÓTELES. Poética. Ed trilíngue por V.G.Yebra. Madrid, Gredos, 1974.

BREMMER, J. (Ed.). Interpretations of greek mythology. London, Routledge, 1988.

CAREY, C. The second stasimon of Sophocles' Oedipus Tyrannus. In: JHS, vol. CVI, 1986, Oxford, Alden Press. p. 175-9.

CROISET, M. Oedipe-Roi de Sophocle. Paris, Mellottée, 1935.

DAWE, R.D. Sophocles Oedipus Rex. Cambridge, Cambridge U.P, 1982.

DELCOURT, Marie. Légendes et cultes de héros en Grèce. Paris, Leroux, 1942. . Oedipe ou la légende du conquérant. Paris, Les Belles Lettres, 1981.

DODDS, E.R. On misunderstanding the Oedipus Rex. In: Greece \& Rome, nº13, 1966. p. 37-49.

EDMUNDS, Lowel. Oedipus - the ancient legend and its later analogues. Baltimore, The Johns Hopkins U.P, 1985.

EHRENBERG, V. The greek state. Oxford, Basil Blackwell, 1960.

ERRANDONEA, Ignácio. El estasimo segundo del Edipo Rey de Sofocles. s/l, Eva Perón, 1952.

EUBEN, J.P. Greek tragedy and political theory. Berkeley, University of California Press, 1986.

FINLEY, Moses I. A política no mundo antigo. Rio de Janeiro, Zahar, 1985.

FOUCAULT, Michel. A verdade e as formas jurídicas. In: Cadernos da PUC, Série Letras e Artes, Rio de Janeiro, 06/1974.

GOULD, John. On making sense of greek religion. in: EASTERLING, P.E. \& MUIR, J.V. (Ed.). Greek Religion \& Society. Cambridge, Cambridge U.P, 1985.p. 1-33.

HARRY, J.E. De exordis Oedipodis tyranni Sophocleae. In: Mn, XLV. p. 441-4.

HERÓDOTO (ERODOTO). Storie (4 vols). Ed. bilíngüe com tradução de Augusta Izzo D’Accinni. Milano, B.U.R, 1988.

JEBB, Sir Richard C. Sophocles - the plays \& fragments. Part I : The Oedipus Tyrannus. Amsterdam, Adolf M. Hakkert, 1966.

JONES, John. On Aristotle and greek tragedy. Stanford, Stanford U.P, 1980.

KAMERBEEK, J.C. The plays of Sophocles; commentaries, part IV : the Oedipus Tyrannus. Leiden, E.J. Brill, 1967.

KNOX, B.M.W. Oedipus at Thebes. New York, The Norton Library, 1971 (1957 - Yale U.P). Why is Oedipus called Tyrannos? In: $C J$, vol. 50, $\mathrm{n}^{\circ} 3,1954$. 
Sophocles and the polis. In: Romilly, Jacqueline de, Sophocle. (Fondation Hardt Entretiens), tomo XXIX, Genebra, Vandoeuvres-Genève, 1983.

LÉVI-STRAUSS, Claude. Antopologie structurale. Paris, Lib. Plon, 1958.

LLOYD-JONES, Hugh, \& WILSON, N.G. Sophoclea; studies on the text of Sophocles. Oxford, Clarendon Press, 1990.

LLOYD-JONES, Hugh. Greek epic, lyric \& tragedy. Oxford, Clarendon Press, 1990.

The justice of Zeus. Los Angeles, University of California Press, 1971.

MAZON, P. \& DAIN, A. Sophocle - Tome II : Ajax, Oedipe Roi et Eléctre. Paris, Les Belles Lettres, 1989.

MOORHOUSE, A.C. The syntax of Sophocles. Leiden, E.J.Brill, 1982.

O'BRIEN, Michael J. Twentieth century interpretations of Oedipus Rex. Englewood Cliffs, Prentice Hall, 1968.

PERADOTTO, John. Disauthorizing prophecy: the ideological mapping of Oedipus Tyrannus. In: TAPA, nº122, 1992. p. 1-15.

PIGNARRE, R. Sophocle. Paris, Flammarion, 1964.

PROPP, Vladimir. Édipo à luz do folclore. Lisboa, Editorial Vega, s/d [Leningrado, 1944].

REINHARDT, Karl. Sophocle. Paris, Les Editions du Minuit, 1971.

ROCHA, Maria Christina de C. F. O discurso político no Édipo-Rei de Sófocles. in: FÉLIX, Loiva O. e GOETTEMS, Míriam B. (orgs.), Cultura Grega Clássica. Porto Alegre, Editora da Universidade/Ufrgs, 1989, p. 22-35;

TORRANO, Jaa. O Sentido de Zeus. São Paulo, Iluminuras, 1996. [Roswitha Kempf, 1988]

WHITE, Mary. The meaning of Tyranny. In: KAGAN, D. Problems in ancient history. New York, MacMillan, 1975. p. 242-7. 